\title{
Influence of Spacing and Pruning on Growth Characteristics, Yield and Economics of Tomato (Solanum lycopersicum L.) Grown Under Protected Environment
}

\author{
Harmanjeet Singh* , Parveen Sharma, Pardeep Kumar and Navjot Singh Dhillon
}

Department of Vegetable Science and Floriculture, CSK HPKV, Palampur-176062 (H.P.), India *Corresponding author

\section{A B S T R A C T}

\begin{tabular}{|l|}
\hline Ke y w o r d s \\
Plant spacing, \\
$\begin{array}{l}\text { Pruning, Protected } \\
\text { environment, } \\
\text { Tomato, Growth } \\
\text { and Yield. }\end{array}$ \\
\hline Article Info \\
\hline $\begin{array}{l}\text { Accepted: } \\
\text { 21 July 2017 } \\
\text { Available Online: } \\
\text { 10 September } 2017\end{array}$
\end{tabular}

\section{Introduction}

Tomato (Solanum lycopersicum L.) is one of the most important vegetable crops grown under the protected environment in India. Area of this crop under the protected environment is increasing day by day due to higher as well as quality returns from inside environment as compared to the open field conditions. Tomato belongs to family Solanaceae with diploid chromosome number $(2 \mathrm{n}=24)$ and is a typical self-pollinated day neutral plant (Yadav et al., 2017). Vegetable production, profits are greatly dependent on the quantity and quality of the yield of the crop. Under the polyhouse conditions plant geometry is an important factor for optimum crop stand and to get maximum return per unit area and time. Pruning of leaves and side shoots also reported to enhance the ultimate yield in various ways. Training maximizes the plant's ability to obtain the sunlight needed for growth and development (Gou et al., 1991). It is also important to maintain adequate air movement around the plant to reduce risk of fungus and insect problems. A dense canopy of leaves shades the fruits, causing them to be pale (Herbert, 1998). Relatively high perishability has made tomato plants to be more vulnerable to intensive crop 
management and unfavorable environmental conditions. Excessive pruning of leaves sometimes causes the plants to cease producing flowers. Therefore, it is important to maintain sufficient foliage on the plant for adequate rates of photosynthesis. Manipulation of canopy architecture through pruning and training together with appropriate spatial arrangements has been identified as key management practices for getting maximum marketable yields from polyhouse crops (Cabula, 1995; Lorenzo and Castilla, 1995; Gou, 1991). In this study the main emphasis was given on appropriate cultural practices such as plant densities and training systems in order to enhance the production per unit area by utilizing the available space and utilization of the resources.

\section{Materials and Methods}

Experiment was carried out in a modified naturally ventilated polyhouse having $250 \mathrm{~m}^{2}$ area at experimental farm of Department of Vegetable Science and Floriculture, CSK Himachal Pradesh Krishi Vishvavidyalaya, Palampur during spring-summer 2016 and autumn-winter 2016-17 seasons. The experiment was laid out in a Factorial Randomized Block Design (RBD) with three replications, consisting of two treatments i.e., $70 \times 30 \mathrm{~cm}$ spacing with two stems pruning $\left(\mathrm{G}_{1}\right)$ and $70 \times 60 \mathrm{~cm}$ spacing with three stems pruning $\left(\mathrm{G}_{2}\right)$. For the present investigation on high yielding and bacterial wilt resistant hybrid "Palam Tomato Hybrid-1" was selected and seeds were sown in plastic plug trays by using soilless media having cocopeat, perlite and vermiculite in the ratio of $3: 1: 1$, respectively inside the growth chamber to get healthy and disease free seedlings of tomato. The observations were recorded on the traits viz., days to 50 per cent flowering, days to first harvest, number of nodes/plant, internodal length, plant height, number of fruits/plant, average fruit weight, yield per meter square, harvest duration, net returns and output: input ratio. Observations were recorded on 5 plants taken at random in each entry. The data pertaining to the present investigation were statistical analyzed using the standard procedures of the Factorial Randomized Block Design (RBD) as described by Gomez and Gomez (1983).

\section{Results and Discussion}

Data (Table 1) revealed that plant geometries had significant influence on growth and yield parameters of tomato under protected environment. Plant geometry $\mathrm{G}_{1}$ i.e. closer spacing of $70 \times 30 \mathrm{~cm}$ with 2 stems pruning took significantly lesser number of days for flowering (33.9 days) than wider spacing of $70 \times 60 \mathrm{~cm}$ with 3 stems pruning (35.4 days). This might be due to early shift in vegetative to reproductive stage in plants pruned to 2 stems. The availability of more photosynthates because of 2 stems were maintained per plant.

These results are in conformity with the findings of Ara et al., (2007) who had also reported that the plants with two shoots took minimum days to flowering initiation. The results pertaining to early flowering compared to wider spacing are also in close conformity with the findings of Muhammad-Ibrahim et al., (1996) and Kumar (1999). Plant geometry $\mathrm{G}_{1}(70 \times 30 \mathrm{~cm}$ spacing with 2 stems pruning $)$ also took significantly lesser number of days (84.3 days) to first harvest than $G_{2}(70 \times 60$ $\mathrm{cm}$ spacing with 3 stems pruning). Early fruit setting coupled with exposure of fruits to sunlight and aeration could be the reasons for early picking in plants pruned to 2 stems. Similar results were also reported by Yadav et al., (2017).

Plant geometry also had significant effect on number of nodes/plant, internodal length and plant height (Table 1). Plant geometry $\mathrm{G}_{2}$ recorded significantly higher number of nodes/plant (32.9) compared to $\mathrm{G}_{2}(31.8)$. 
Table.1 Effect of plant geometry on days to 50 per cent flowering, day to first harvest, number of nodes/plant, internodal length $(\mathrm{cm})$ and plant height $(\mathrm{cm})$

\begin{tabular}{|c|c|c|c|c|c|c|c|c|c|c|c|c|c|c|c|}
\hline \multirow[t]{2}{*}{ Treatment } & \multicolumn{3}{|c|}{$\begin{array}{c}\text { Days to } 50 \text { per cent } \\
\text { flowering }\end{array}$} & \multicolumn{3}{|c|}{ Day to first harvest } & \multicolumn{3}{|c|}{$\begin{array}{c}\text { Number of } \\
\text { nodes/plant }\end{array}$} & \multicolumn{3}{|c|}{$\begin{array}{l}\text { Internodal length } \\
(\mathbf{c m})\end{array}$} & \multicolumn{3}{|c|}{$\begin{array}{c}\text { Plant height } \\
\text { (cm) }\end{array}$} \\
\hline & 2016 & 2017 & Pooled & 2016 & 2017 & Pooled & 2016 & 2017 & Pooled & 2016 & 2017 & Pooled & 2016 & 2017 & Pooled \\
\hline \multicolumn{16}{|c|}{ Plant geometry } \\
\hline $\mathrm{G}_{1}$ & 34.9 & 32.7 & 33.9 & 75.3 & 93.3 & 84.3 & 36.6 & 27.1 & 31.8 & 6.8 & 8.4 & 7.6 & 245.1 & 226.4 & 235.8 \\
\hline $\mathrm{G}_{2}$ & 36.6 & 34.7 & 35.4 & 77.0 & 95.9 & 86.4 & 36.7 & 29.0 & 32.9 & 6.2 & 7.7 & 7.0 & 225.5 & 220.0 & 222.7 \\
\hline $\mathrm{SEm} \pm$ & 0.4 & 0.4 & - & 0.6 & 0.6 & 0.3 & - & 0.4 & 0.3 & 0.1 & 0.1 & 0.1 & 0.7 & 0.5 & 0.4 \\
\hline $\mathrm{CD}(\mathrm{P}=0.05)$ & 1.0 & 1.2 & NS & 1.6 & 1.8 & 1.0 & NS & 1.0 & 0.9 & 0.3 & 0.3 & 0.2 & 1.9 & 1.5 & 1.0 \\
\hline
\end{tabular}

NS = Non-significant

Table.2 Effect of plant geometry on fruits/plant, fruit weight $(\mathrm{g})$, yield per meter square $\left(\mathrm{kg} / \mathrm{m}^{2}\right)$, harvest duration (days) and output: input ratio

\begin{tabular}{|c|c|c|c|c|c|c|c|c|c|c|c|c|c|c|c|}
\hline \multirow[t]{2}{*}{ Treatment } & \multicolumn{3}{|c|}{ Fruits/ plant } & \multicolumn{3}{|c|}{ Fruit weight (g) } & \multicolumn{3}{|c|}{$\begin{array}{c}\text { Yield/ meter square } \\
\qquad\left(\mathrm{kg} / \mathrm{m}^{2}\right)\end{array}$} & \multicolumn{3}{|c|}{$\begin{array}{c}\text { Harvest duration } \\
\text { (days) }\end{array}$} & \multicolumn{3}{|c|}{ Output: input ratio } \\
\hline & 2016 & 2017 & Pooled & 2016 & 2017 & Pooled & 2016 & 2017 & Pooled & 2016 & 2017 & Pooled & 2016 & 2017 & Pooled \\
\hline \multicolumn{16}{|c|}{ Plant geometry } \\
\hline $\mathrm{G}_{1}$ & 36.6 & 34.4 & 35.5 & 54.46 & 55.3 & 54.9 & 12.2 & 11.7 & 12.0 & 69.2 & 86.9 & 78.1 & 3.0 & 2.9 & 3.0 \\
\hline $\mathrm{G}_{2}$ & 41.4 & 38.8 & 40.1 & 56.43 & 59.5 & 58.0 & 7.2 & 7.1 & 7.1 & 76.1 & 91.6 & 83.8 & 2.4 & 2.4 & 2.4 \\
\hline $\mathrm{SEm} \pm$ & 0.7 & 0.4 & 0.3 & 0.27 & 0.4 & 0.2 & 0.2 & 0.2 & 0.1 & 0.5 & 0.6 & 0.3 & 0.0 & 0.0 & $\mathbf{0 . 0}$ \\
\hline $\mathrm{CD}(\mathrm{P}=0.05)$ & 2.0 & 1.1 & 0.9 & 0.76 & 1.2 & 0.6 & 0.5 & 0.4 & 0.3 & 1.5 & 1.8 & 0.9 & 0.1 & 0.1 & 0.1 \\
\hline
\end{tabular}


Table.3 Effect of plant geometry on fruit yield $\left(\mathrm{kg} / \mathrm{m}^{2}\right)$, cost of cultivation $\left(\mathrm{Rs} . / \mathrm{m}^{2}\right)$, gross returns (Rs. $\left./ \mathrm{m}^{2}\right)$ and net returns $\left(\mathrm{Rs} . / \mathrm{m}^{2}\right)$

\begin{tabular}{|c|c|c|c|c|c|c|c|c|c|}
\hline \multirow{2}{*}{ Treatment } & \multicolumn{3}{|c|}{ Cost of cultivation (Rs./m²) } & \multicolumn{3}{|c|}{ Gross returns (Rs./m²) } & \multicolumn{3}{|c|}{ Net returns (Rs./m² } \\
\hline & 2016 & 2017 & Pooled & 2016 & 2017 & Pooled & 2016 & 2017 & Pooled \\
\hline \multicolumn{10}{|c|}{ Plant geometry } \\
\hline $\mathrm{G}_{1}$ & 80.3 & 80.3 & 80.3 & 244.6 & 234.1 & 239.3 & 164.3 & 153.8 & 159.0 \\
\hline $\mathrm{G}_{2}$ & 60.5 & 60.5 & 60.5 & 143.6 & 142.0 & 142.8 & 83.2 & 81.5 & 82.4 \\
\hline $\mathrm{SEm} \pm$ & 0.5 & 0.5 & 0.5 & 3.2 & 1.1 & 1.4 & 1.63 & 1.2 & 0.8 \\
\hline $\mathrm{CD}(\mathrm{P}=0.05)$ & 1.4 & 1.5 & 1.5 & 9.2 & 3.1 & 4.0 & 4.67 & 3.5 & 2.3 \\
\hline
\end{tabular}

Fig.1 Effect of plant geometries on fruit/plant, fruit weight $(\mathrm{g})$, yield/meter square $\left(\mathrm{kg} / \mathrm{m}^{2}\right)$ and number of plants/ meter square

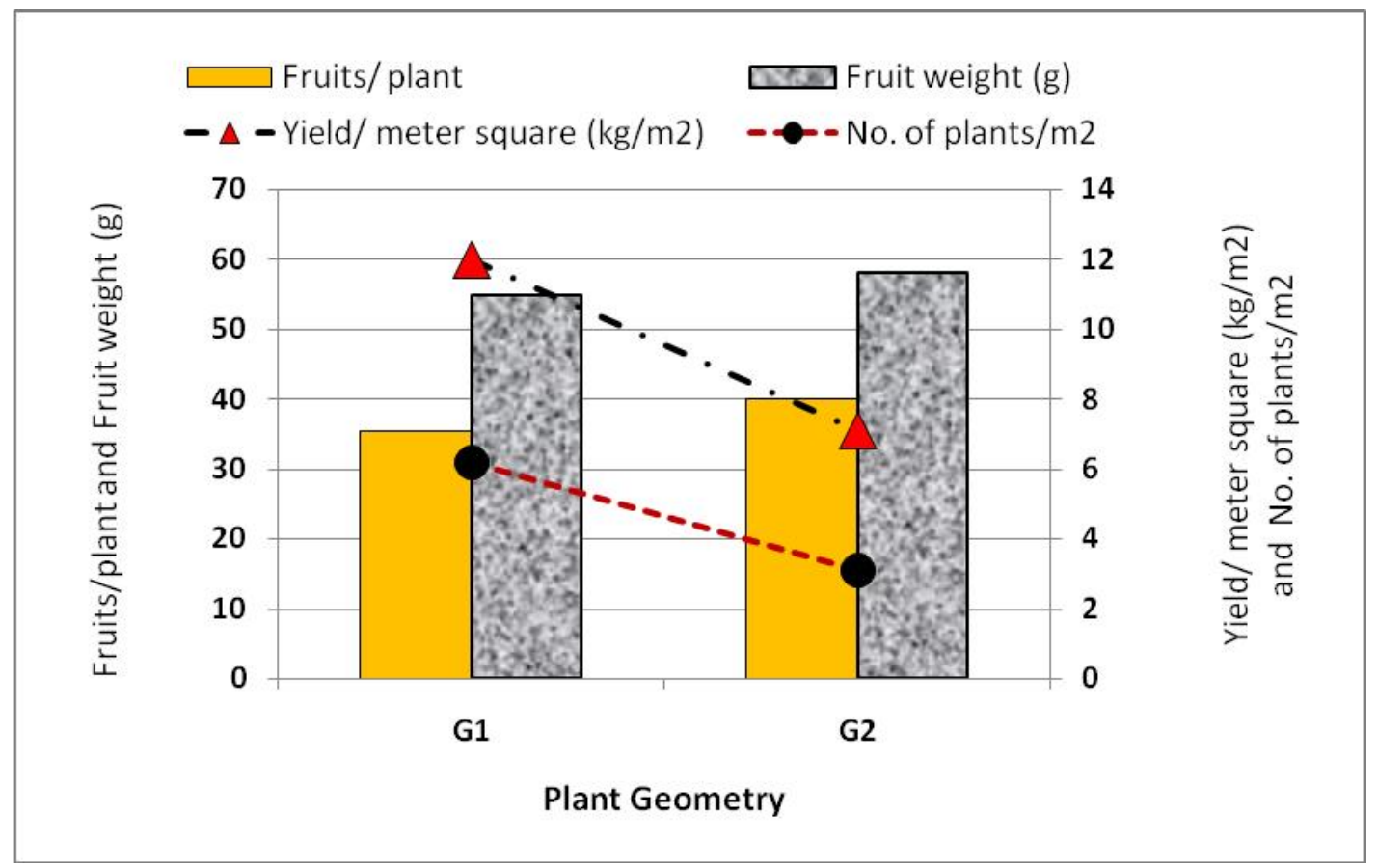

This could be due to increase in a number of stems/plant. The minimum internodal length recorded when plants were spaced at $70 \times 60$ $\mathrm{cm}$ with 3 stems pruning $\left(\mathrm{G}_{2}\right)$ and was statistically superior to $70 \times 30 \mathrm{~cm}$ with 2 stems pruning $\left(G_{1}\right)$. This might be due to sufficient light intensity. Papadopoulos and Ormrod (1990) also recorded less internodal length in wider spacing plants. The plant height was enhanced with a decrease in plant geometry. The highest plant height (235.8 $\mathrm{cm}$ ) was recorded at $\mathrm{G}_{1}$ gave statistically superior to $G_{2}$. This might be due to plants with 2 stems pruning causing more nutrients flow toward apical tissues then axillary branches which enhances plant height and is more supported by less spacing on account of more competition posed for space and light there by forcing plants to grow taller. The short plants were produced at wider spacing because of 3 stems pruning. Similar observations were also reported by Alam et al., (2011) and Razzak et al., (2013).

Plant geometry of $70 \times 60 \mathrm{~cm}$ with 3 stems pruning $\left(\mathrm{G}_{2}\right)$ produced significantly more 
number of fruits/plant than closer spacing of $70 \times 30 \mathrm{~cm}$ with 2 stems pruning $\left(\mathrm{G}_{1}\right)$ (Table 2 , Figure 1). This might be due to increased availability of growth favouring components viz., nutrients, air and moisture at wider spacing. Similar findings have been reported by Alam et al., (2011) and Amundson (2012). Fruits produced at wider plant geometry of 70 $\times 60 \mathrm{~cm}$ with 3 stems pruning $\left(\mathrm{G}_{2}\right)$ gave significantly higher average fruit weight $(58.0$ g) than the closer geometry of $70 \times 30 \mathrm{~cm}$ with 2 stems pruning $\left(\mathrm{G}_{1}\right)$ (Table 2$)$. This could be due to increased uptake of more nutrients and buildup of sufficient photosynthates enabling the increase in size of fruits (length and breadth), ultimately resulted in the increase fruit size. The results are in conformity with the findings of Kirimi et al., (2011) and Bhattarai et al., (2015). Highest fruit yield $/ \mathrm{m}^{2}$ area $\left(12.0 \mathrm{~kg} / \mathrm{m}^{2}\right)$ was resulted with the closer spacing of $70 \times 30 \mathrm{~cm}$ with 2 stems pruning $\left(\mathrm{G}_{1}\right)$ and lowest $(7.1$ $\mathrm{kg} / \mathrm{m}^{2}$ ) with the wider spacing at $70 \times 60 \mathrm{~cm}$ with 3 stems pruning $\left(\mathrm{G}_{2}\right)$ (Table 2$)$. This might be due to more number of plants and fruits per unit areas in close spacing which leads to higher yield $/ \mathrm{m}^{2}$.

Data presented in table 2 revealed that plant geometry had significant influence on harvest duration and Output: input ratio. $\mathrm{G}_{2}$ i.e. wider spacing of $70 \times 60 \mathrm{~cm}$ with 3 stems pruning (83.8 days) resulted in prolonged harvest duration than $G_{1}$ i.e. closer spacing of $70 \times 30$ $\mathrm{cm}$ with 2 stems pruning (86.9 days). This might be due to more exposure of plant to light in wider spacing as compared to closer one. Similarly in two stems pruning system, less number of fruits occur which leads to shorter harvest duration. Similar results were also reported by Khoshkam et al., (2014). Highest net returns (Rs.159.0/m ${ }^{2}$ ) were recorded at a closer plant spacing $70 \times 30 \mathrm{~cm}$ with 2 stems $\left(G_{1}\right)$, which was significantly higher than wider plant spacing $70 \times 60 \mathrm{~cm}$ with 3 stems $\left(\mathrm{G}_{2}\right)$ (Rs.82.4 $\left./ \mathrm{m}^{2}\right)$ (Table 3).
This might be due to higher plant population and higher gross return/unit area at narrow spacing. Similarly, the highest Output: Input ratio (3.0) was resulted at a closer spacing 70 $\times 30 \mathrm{~cm}$ with 2 stems pruning $\left(\mathrm{G}_{1}\right)$, gave significantly higher yield than at wider spacing of $70 \times 60 \mathrm{~cm}$ with 3 stems pruning $\left(\mathrm{G}_{2}\right)$. This might be due to higher plant population (Figure 1) and higher net return/unit area at narrow spacing.

Based upon present results, it can be concluded that plant geometry $\mathrm{G}_{1}$ significantly increased the yield and yield contributing characters in tomato under the protected environment. Plants under $\mathrm{G}_{1}$ had maximum yield $/ \mathrm{m}^{2}$, higher net return/unit area and highest output: input ratio.

\section{References}

Alam, M.S., Saha, S.R., Salam, M.A. and Alam, M.K. 2011. Effect of sowing time and plant spacing on the yield and yield attributes of sweet pepper (Capsicum annum). Bangladesh Journal of Agriculture Research. 36: 271-278.

Amundson, S.K., 2012. Cultural techniques to improve yield and cost efficiency of greenhouse grown tomatoes. M Sc Thesis, $p$ 90. Department of Plant Sciences, University of Tennessee, Knoxville.

Ara, N., Bashar, M.K., Begum, S. and Kakon, S.S. 2007. Effect of spacing and stem pruning on the growth and yield of tomato. International Journal of Sustainable Crop Production. 2: 35-39.

Bhattarai, P., Kaushik, R.A., Ameta, K.D., Jain, H.K., Kaushik, M.K. and Sharma, F.L. 2015. Effect of plant geometry and fertigation on growth and yield of cherry tomato (Solanum lycopersicon var. cerasiforme) under zero energy polyhouse conditions. Indian Journal of Horticulture. 72: 297-301. 
Cebula, S., 1995. Optimization of plants and shoot spacing in greenhouse production of sweet pepper. Acta Horticulturae. 412: 321-328.

Gomez, K.A., and Gomez, A.A. 1983. Statistical procedures for agricultural research. John Wiley and Sons series, 2nd edition.

Guo, F.C., Fujime, Y., Hirose, T. and Kato, T. 1991. Effects of the number of training shoots, raising period of seedlings and planting density in growth, fruiting and yields of sweet pepper. Journal of the Japanese Society for Horticultural Science. 59: 763-770.

Herbert, M., 1998. Greenhouse cucumber production. http://www.uaf.edu.

Khoshkam, S., Seyedi, Z. and Aeen, A. 2014. The impact of different plant training systems on quantitative and qualitative parameters of greenhouse tomato cultivars. International Journal of Farming and Allied Sciences. 3: 659663.

Kirimi, J.K., Itulya, F.M. and Mwaja, V.N. 2011. Effects of nitrogen and spacing on fruit yield of tomato. African Journal Horticulture Science. 5: 50-60.

Kumar, N., 1999. Effect of fertility levels and spacing on growth, yield and quality of tomato (Lycopersicon esculentum Mill.) hybrid Cv. BSS-20. M Sc Thesis, RAU,
Bihar.

Lorenzo, P., and Castilla, N. 1995. Bell pepper yield response to plant density and radiation in unheated plastic greenhouse. Acta horticultura. 32: 149158.

Muhammad-Ibrahim, Ali, N., Muhammad, N. and Khalid-ur-Rahim. 1996. Interplant spacing and cycocel affect plant growth and yield of Lycopersicon esculentum L. Sarhad Journal of Agriculture. 12: 117-21.

Papadopoulos, A.P., and Ormrod, D.P. 1990. Plant spacing effects on yield of the greenhouse tomato. Canadian Journal of Plant Science. 70: 565-573.

Razzak, H.A., Ibrahim, A., Wahb-Allah, M. and Alsadon, A. 2013. Response of cherry tomato (Solanum lycopersicum var. cerasiforme) to pruning systems and irrigation rates under greenhouse condition. Asian Journal of Crop Science, 64: 321-332.

Yadav, S., Ameta, K.D., Sharma, S.K., Dubey, R.B., Rathore, R.S., Kumar, H. and Kapuriya, V.K. 2017. Effect of spacing and training on vegetative growth characteristics and yield of tomato (Solanum lycopersicum L.) grown in polyhouse. International Journal of Current Microbiology and Applied Sciences. 6: 1969-1976.

\section{How to cite this article:}

Harmanjeet Singh, Parveen Sharma, Pardeep Kumar and Navjot Singh Dhillon. 2017. Influence of Spacing and Pruning on Growth Characteristics, Yield and Economics of Tomato (Solanum lycopersicum L.) Grown Under Protected Environment. Int.J.Curr.Microbiol.App.Sci. 6(9): 1833-1838. doi: https://doi.org/10.20546/ijcmas.2017.609.226 